\title{
THE LIFE HISTORY OF "DIAPREPES ABBREVIATUS" L., AT RIO PIEDRAS, PUERTO RICO.
}

\author{
By George N. WolcotT,
}

Entomologist, Agricultural Experiment Station, Río Piedras, P. R.

Less is known about the details of the life-histories of the Otiorhynchid weevils of the genera Pachnaeus, Prepodes, Exophthalmodes (or Exophathalmus) and Diaprepes than of any of the other common and comparatively large insects of the West Indies. This is all the more surprising because some of them are economic pests of primary rank, and at least in Puerto Rico and Barbados at the present time, they appear to be of relatively increasing importance.

The early work of the Rev. Watson on Diaprepes abbreviatus in Barbados in 1903 (15) and of Cook \& Horne on Pachnaeus litus in Cuba in 1908 (3) is based on conclusions drawn from only a few individuals, and later workers have merely added field observations to form a tentative theory of what actually takes place during the subterranean period of development. With many insects, no serious error would be involved, but this group of weevils, and especially Diaprepes abbreviatus, displays such a wide variation in practically every aspect of its being that more exact information should be available. Attempts at rearing under close observation from egg to adult were first seriously attempted by the writer in Haiti in 1929, using Prepodes quadrivittatus (17), and later were resumed in Puerto Rico using Diaprepes abbreviatus (19). The development of a successful rearing technique (21) permitted the completion of a sufficient number of case histories to make possible this finai report. Admittedly, the present paper treats of only one species at a single locality, but the determination of what factors are responsible for the wide variation shown by the individuals of this species in a single environment is still so uncertain that it seems desirable to present the data now available, which may serve as a basis for comparison with observations on this and other species in similar or quite different environments. 
The diversity of the scientific names of the various members of this group of weevils should not obscure the fact that the insects themselves are iundamentaliy very similar, and indeed the points on which the genera are distinguished are so difficult to discover that to one species, quadrivittcitus Olivier of Hispaniola, four generic names (all except Pachnaeus) have been applied in recent times by specialists in the nomenclature of Curculionidae. Not only do the systematists effectively fail to note esential differences, but the recent discovery that the egg-parasite, Tetrastichus haitiensis Gahan, attacks Pachnaeus litus in Cuba (2), Prepocies quadrivittatus in Haiti (from which it was originally described: 6), Diaprepes abbreviatus in Puerto Rico and D. famelicus in Montserrat (11) sufficiently indicates the fundamental similarlity of these beetles as it appears to a specialized insect directly dependant on them for its existence. Moreover, from the standpoint of the farmer, the injury caused by these pests is practically the same everywhere that they cccur in abundance, and is a single problem so far as the eitrus or cane grower is concerned, regardless of what the entomolugist calls the insect responsible.

Rarely are mature citrus trees in groves in Puerto Rico severely injured by the feeding of "vaquitas", as the adults of Diaprepes abbreviatus L. are locally called, altho several complaints have been received of injury to large trees. Nurseries and young trees just set out in the grove are much more often attacked, or at least the feeding of the beetles is more obvious to the grower on such small trees. The beetles feed almost exclusively on young tender foliage, altho when exceptionally abundant, they may attack the older leaves. Due to seasonal abundance of the weevils, most of the young foliage may be consumed at one time, while a later flush of growth escapes without commercial injury, but instances have been noted of trees being so repeatedly defoliated that they eventually died. Their death was presumably due to a combination of circumstances, for undoubtedly at the same time the grubs of Diaprepes were feeding on their roots. This only serves to emphasize, however, the dual nature of the injury caused by this insect in citrus groves: of the adults to the leaves, and of the grubs to the roots.

Vaquitas feed on the leaves of many other kinds of trees 
besides citrus, and, especially in the case of those trees which obtain all their new leaves at the same time, such as the "moca", Andira inermis, often completely denude them of their leaves so that they remain defoliated for the remainder of the year. Or trees are sometimes noted that remain practically defoliated despite the constant production of new leaves. Young trees of "ceiba", Ceiba pentandra, have been observed with only a comparatively few vaquitas on them, yet even a few beetles (with their numbers constantly renewed as the older ones disappear) eating only the yong leaves succeed in keeping the foliage permanently ragged.

Solitary vaquitas are found, especially in cane fields, but the adult weevils are essentially social in their habits. Dozens are often to be seen congregated on the young growth of small trees, and large trees being denuded of a flush of tender growth may harbor thousands at one time. For no ascertainable reason, particular trees are often preferred by the beetles to others of the same kind nearby, and even tho the beetles are free to move about and fly to others, they often remain congregated on such trees for weeks at a time. If disturbed by the presence of man, some individuals drop to the earth and crawl away between the vegetation, or, if on bare earth, clumsily run for cover. Others drop, but take flight before reaching the ground, while others clamber to a more protected situation on the host, or fly from it. In captivity, one continually hears the sound of their dropping to the bottom of the can, and presumably dropping to the ground is a common, natural habit, even when not disturbed.

The beetles apparently feed at all times of the night and day, but many are merely resting in the company of others, while numerous pairs are to be observed in coitu. In confinement, the elytra of the males often become densely covered with excrement, but in nature they remain clean and immaculate. Sometimes solitary vaquitas are attracted to lights at night, even as high as the second story of houses, and presumably they fly as readily at night as in the daytime.

The feeding of the beetles, for the most part, is due to the requirements of the female in the production of eggs, dropping off rapidly when she has ceased to oviposit, while that of the males is insignificant by comparison. The female during oviposition eats her own weight of food in a day. This is hardly 
surprising considering that during her life-time she lays eggs sometimes weighing four or five times as much as she herself weighs. The eggs represent much more concentrated energy than do the tender leaves, which explains the tremendous demands of the female, depending on such innutrituous food, if she is to produce them.
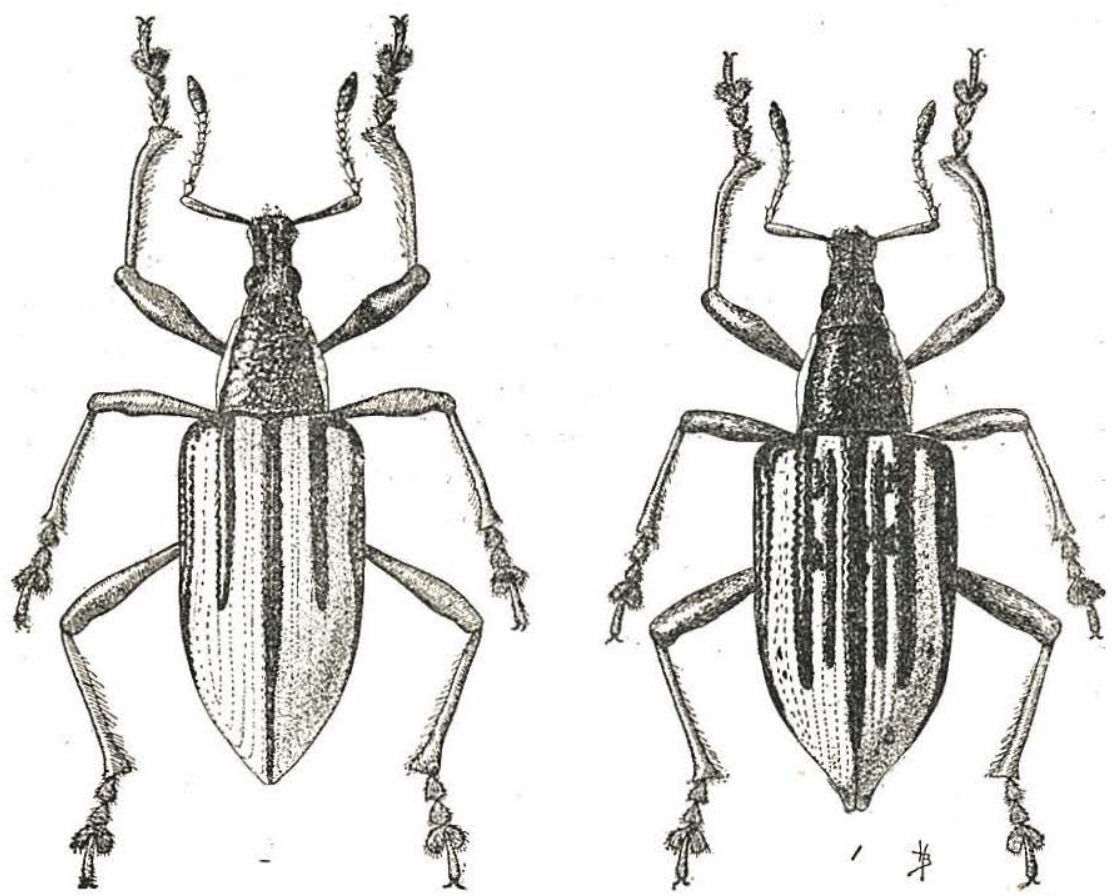

Fig. 1. Adults of Diaprepes abbreviatus L., five times natural size. (After Pierce.)

In captivity, adults live four or five months after they have transformed from the pupa, but often half of this time is spent below the surface of the ground. After the adult emerges from the ground, it never returns to burrow into it. Some adults live much longer than do others, the maximum number of days being 336, 295 and 262 for three females, and (rather doubtfully) 323 days for a male. The average is much less than this, however, for sixteen males being 123 days and for thirteen females 160 days.

The period of activity of the adults above ground is much less, averaging less than two months for all the males observed, 
but over four months for the observed females, apparently indicating that the males spend considerably more than half of their shorter adult life below the surface of the ground, and the females very much less of their total time thus inactive. The females have a very definite objective in living: oviposition, which occupies all of their aerial adult life from less than a week after emergerice from the soil until a slightly longer period after the final egg-cluster is laid. They are very tenacious of life (in captivity), and altho not at all active in old age, may yet survive for several days after becoming too weak to crawl about. Rarely do the males show sny such gradual decay of their faculties, being apparently normally active one day, and dead the next.

In observing the females for oviposition, one male was always caged with a female, and in practically every case the female outlived not only one, but usually two males successively supplied to her as mates. In nature, the adults are often noted in coitu, and it seems probable that they are promiscuous in mating. Infertile eggs have never been noted, and presumably do not occur under normal conditions, individuals being sufficiently common so that no female should lack long for a mate. The number of adults reared of which the sex was determined was too small to accurately gauge the proportion of sexes, but indicates that the males are somewhat more numerous and possibly may be much move numerous. The apparent preponderance of males can not be due to a smaller amount of food available for the larvae, or, it is posible that, males being normally much more numerous, the intensive feeding of the grubs in captivity resulted in a somewhat abnormal number of females.

"Measurements of 82 males and 63 females taken at Rio Piedras on October 31, 1913, showed the average size of the females to be somewhat greater than the average size of the males. Some males were much larger than some females and some females smaller than some males, but no male was as iarge as the largest female and no females as small as the smallest male.

"The sexes can be distinguished externally by an examination of the last segment of the ventral surface of the abdomen. In the female the sides of this segment are straight and 
converge to a distinct point at the tip, while in the male the sides are somewhat curved, curving in towards the rounded tip of the segment." (8)

Oviposition has not been observed. The original MS of Thos. H. Jones ( $\delta$ ) contains the statement that "the eggs are deposited at night," altho this was crossed out by him before it was submitted for publication. So far as the writer's observations go, this statement is, without exception, entirely correct, at least for beetles in captivity. After fresh food and paper was supplied in the morning to pairs under observation, never has a single egg-ciuster been found by late in the afternoon, while almost invariably one or two clusters of eggs were present the following morning.

Normally, the eggs are laid in clusters between leaves, or between the split tips of a single cane leaf stuck together with an adhesive. To make two shining tough leaves adhere to each other for seven days, until the eggs hatchi, requires an exceptionally effective adhesive, and that used by the female Diaprepes appears to be entirely suitable to its purpose. Only one instance has been noted by the writer of its failure to function perfectly. This was in the case of an exceptionally large egg-cluster, laid between mango leaves during rainy weather, in which one leaf had come free, disclosing the eggs. The female rarely chooses tender leaves, on which the beetles might feed, but rather selects old and tough leaves, usually at some distance from the points where the other beetles are congregated. Sometimes two leaves naturally overlap, and in searching for clusters in the iield, all such overlapping leaves should be examined. Egg-clusters have been found in the field between the tips of cane leaves and of Guinea grass (8), and between two leaves of jobo, mango, wild fig, caimito, eggplant and grapefruit, but presumably any two leaves, even of a plant not ordinarily used for food, may be used between which to place the eggs. Indeed, Dr. Herbert Osborn Jr., (20) found that the iemales prefer sheets of paper in captivity, and the writer that they select paper even in the field. In the experiments reported, the area of tough grapefruit leaves suitable for oviposition was several hundred, or thousand, times as great as that of paper exposed, yet two or three times as many clusters were found between the paper flags attached to the stakes to which the 
nursery trees were tied, as between the leaves of the trees beneath, when examined at two or three day intervals.

Paper was invariably supplied to all the females in captivity on which observations on oviposition were being made, and the great bulk of the records are from eğg-clusters laid between sheets of semi-transparent, oiled paper. Of course this does not simulate conditions in the field, but neither does confinement in a can, and limitation to companionship without a single male, but by providing a stimuius that at least counterbalanced the unfavorable factors of confinement, it certainly resulted in a large, if not the maximum egg-production.

Observations were made on the oviposition of twelve reared females in captivity. Three females, and as many reared males, kept in a can, and supplied with fresh citrus foliage and oiled paper on alternate days, were the first subjects of observation, but in later experiments, each female, with a male, was kept in a separate can. Reared males were used at first to keep with the females, but after three females had been (apparently) murdered by their mates, only males lacking the mandibular appendages, normally lost in burrowing upward thru the soil from the pupal chamber, were used.

Three to seven days elapsed after the females emerged from the ground before they began oviposition. Few general statements can be made regarding the details of oviposition. In some cases, the clusters laid at first, and those towards the end of the period did not contain as many eggs as those laid in the second, third and fourth weeks, while other females laid substantially as large egg-clusters at one time as at another. Scme females often skipped a day or two, or more, without laving, while others were very regular in their habits. Some females which laid several large clusters each day, had finished oviposition in two months, or less time; others laid only one or two smaller clusters per day, or less, and continued ovipusition for over six months. Most females laid their eggs only between the ciled paper supplied them, a few laid some of their eggs between the paper and leaf, a very few laid some eggs betwe'en leave: even when paper was present. A total of 745 egg-clusters was laic by the twelve females, presumably considerably less than the total if the three murdered females had lived to complete oviposition. Of these clusters, two-thirds contained between 30 
and 88 eggs, one-eighth containing 30 to 39 , and over cnceighth 40 to 49 . Over five-eighths of the clusters contained more than $50 \mathrm{eggs}$, but less than one-eighth contained more than 100 eggs. Eleven clusters containing more than 200 eggs were laid in captivity, the greatest number counted in any cluster being 264 .

The data on average weekly egg-laying are not as enlightening as they would be if three females had not been murdered so early in adult life, and if others with a small daily or we quota, by living so much longer almost equalled the total number of eggs laid by those laying many more eggs in less than

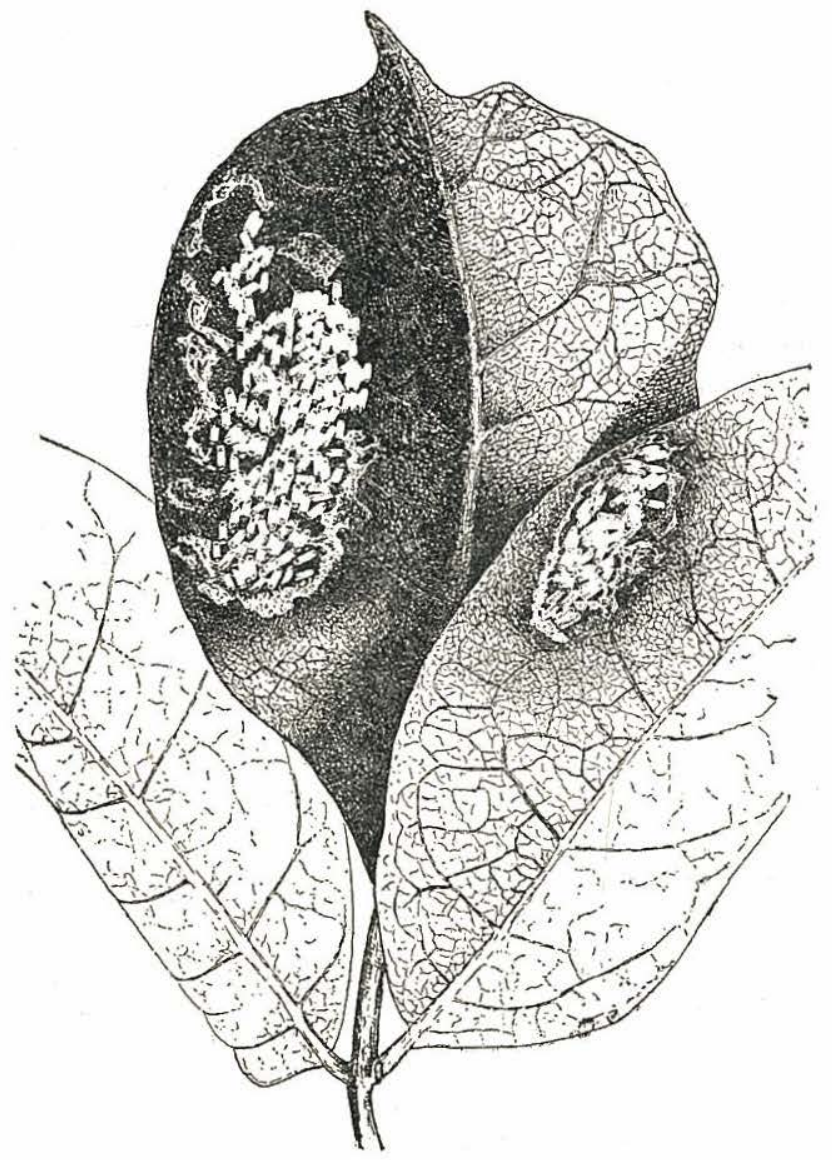

Fig. 2 Egg-clusters of Diaprepes abbreviatus L., between leaves of jobo. Twice natural size. (Drawn by $\mathrm{F}$. Seín). 
half the time. The twelve femitles averaged 469 eggs each during the second week of oviposition, and 622 eggs each during the third week. Ten females averaged 528 eggs each during the fourth week, and nine females 572 eggs during the fifth week. After this, the number of eggs laid appears to slump rapidly, but in reality, the fameles still ovipositing at this time are laying: almost as many eggs as at any previous time, but those laying most eggs have ceased oviposition entirely. Most females lay fewer eggs in the last week previous to ceasing oviposition, but often lay most eggs, or largest clusters on the last day, or days.

One female laid 7,046 eggs between July 2nd and October 2nd, and six females laid nearly or considerably more than 5,000 eggs each during their periods of oviposition. Two others laid nearly or over 3,000 eggs, and three others were prevented from completing oviposition. (See Table No. 1.)

TABLE 1.

Oviposition by Diaprepes abbreviatus L.

\begin{tabular}{|c|c|c|c|c|c|c|c|c|c|c|}
\hline $\begin{array}{l}\text { Number } \\
\text { of } \\
\text { female }\end{array}$ & $U$ & $\mathbf{P}$ & $\begin{array}{c}\text { First } \\
\text { Egg- } \\
\text { Cluster }\end{array}$ & $\begin{array}{c}\text { Last } \\
\text { Egg- } \\
\text { Cluster }\end{array}$ & & $\begin{array}{l}\text { Days } \\
\text { Ovipo- } \\
\text { sition }\end{array}$ & Total & $\begin{array}{c}\text { Eggs } \\
\text { per } \\
\text { Day }\end{array}$ & $\begin{array}{l}\text { Date } \\
\text { of } \\
\text { Death }\end{array}$ & $\begin{array}{l}\text { Cause } \\
\text { of } \\
\text { Death }\end{array}$ \\
\hline 44.1 & April & 28 & May & June & 30 & 5 & 3 & 9 & July & 3 natu \\
\hline & April & 28 & May & July & 9 & 6 & & 9 & July & 14 \\
\hline 4 & May & 7 & May 14 & July & 11 & $5 \varepsilon$ & 5,684 & 96 & July & 16 natur \\
\hline 40.2 & May & 11 & May 16 & June & 26 & 41 & 20 & 71 & June & $28 \mathrm{r}$ \\
\hline 44.3 & June & 28 & July & Oct. & 2 & 92 & 46 & 75 & Oct. & 10 natu \\
\hline 45.11 & Nov. & 20 & Nov. 23 & $\mathrm{Dec}$ & 12 & 1 & 1,293 & 68 & Dec & $\mathrm{mu}$ \\
\hline 47. & Dec & 22 & De & $\mathrm{Ja}$ & 19 & 2 & & 100 & Jan & \\
\hline 47. & Feb. & 8 & Feb. 15 & Mch. & 15 & 28 & 1,675 & 60 & Mch.15 & urder \\
\hline 47.00 & $\mathrm{E}$ & 12 & Feb. 1 & Jun & & 11 & & 4 & June & \\
\hline 7.4 & & 12 & Mch. 1 & $\mathrm{Oc}$ & 7 & 2 & & 2 & Oct. & 14 \\
\hline 7.6 & June & 7 & June 12 & Oct. & 11 & 12 & 5,0 & 41 & Oct. & 26 natur \\
\hline 0. & May & 29 & June 17 & Oct. & 25 & 130 & 3,335 & 24 & Nov. & 3 natur \\
\hline
\end{tabular}

Altho it is not safe to make statements as to anything being normal or average for Diaprepes in most of the details of its life-history, it seems obvious that 5,000 egg's may be considered as a reasonable expectation for most females of the species.

The average of several large egg-clusters indicates that the weight of the individual egg is $.00017 \mathrm{gr}$. Multiplying this by 5,000 gives $.85 \mathrm{gr}$. The minimum weight found for any reared female was $.148 \mathrm{gr}$., the maximum $.35 \mathrm{gr}$. Actually, 
these weights mean but iittle, for when the digestive tract is filled with food and at the same time the ovaries with eggs, the total apparent weight of the temale is much more than immediately after emergence from the ground, or at time of death. Even the net weight may vary considerably, as is shown by the weights of one fernale which on emergence from the ground on June 7th weighed $.175 \mathrm{gr}$., on October 18th, a week after laying her last egg, .246 gr., five days later .222 gr., and .21 gr. on October 26th, on which date she had died. But even after taking: into consideration all of these factors, it is obvious that the eggs laid by a female weigh at least twice as much as her own net weight, and may weigh three, four, or even five times as much as she does.

Normally, egg-clusters consist of only a single layer of eggs, altho sometimes towards the center of large clusters two partial layers may be found. Naturally, having the eggs laid in a single layer simplifies their being counted, and by supplying transparent oiled paper to the females, the counts can be made without disturbing the cggs. The shape of the clusters is usually more or less oval, but rarely are all of the eggs laid in a regular manner. The rows of eggs may at times go straight across, but more often each egg following the first is laid beside the other, but by about half of its length further down, making the rows transverse like those of bricks in ordinary construction. Several rows may be laid thus, and then the female apparently shifts to the other side, continuing by laying transverse rows of eggs in the opposite direction, crowding and doubling them sometimes, and rarely making a regular or even cluster. Some clusters are very elongate, often being only two or three eggs wide in the middle, but with more eggs at either end. On the transparent paper, the outline of the margin of the adhesive used can be plainly seen, extending completely around the outside of the cluster. From the way in which the eggs adhere when the enclosing leaves or papers are separated, it appears that all may have been laid on one leaf, to which the other leaf (or paper) is glued, or some may be on one leaf and some on the other. Trying to describe the typical or average egg-cluster is the more difficult because of the infinite variation displayed.

"The eggs are oblong-oval, smooth, glistening, with a rather tough membranous covering, about $1.2 \mathrm{~mm}$. in length. 
and $.4 \mathrm{~mm}$. in diameter. Newly laid eggs are of a uniform milky white, but within a day or two after being laid, clear spaces appear at either end of the egg, this space being more pronounced at one end. Before hatching, the clear spaces disappear and the egg takes on a faint brownish tinge, the mouth-parts of the larva, contained within, being visible through the walls of the egg." (8)

Seven days after oviposition the eggs hatch. This incubation period is the most constant in an otherwise most variable life-history, and is apparently unaffected by any of the ordinary variations in temperature experienced in the tropics. The escape of the grubs from the confines of the egg-cluster's surrounding layer of adhesive may be delayed for some time, at least judging by the numbers of such grubs found and released when one is attempting to collect fresh or parasitized egg-clusters in the field. As previously reported (20), the adhesive is so effective when the cluster is laid between sheets of papr that the grubs do not escape its confines, and eventually perish. The grubs never attempt to pierce the papers or leaves, but eventually find a thin place in the adhesive, or by their wiggling loosen its hold on one of the leaves so that they can escape.

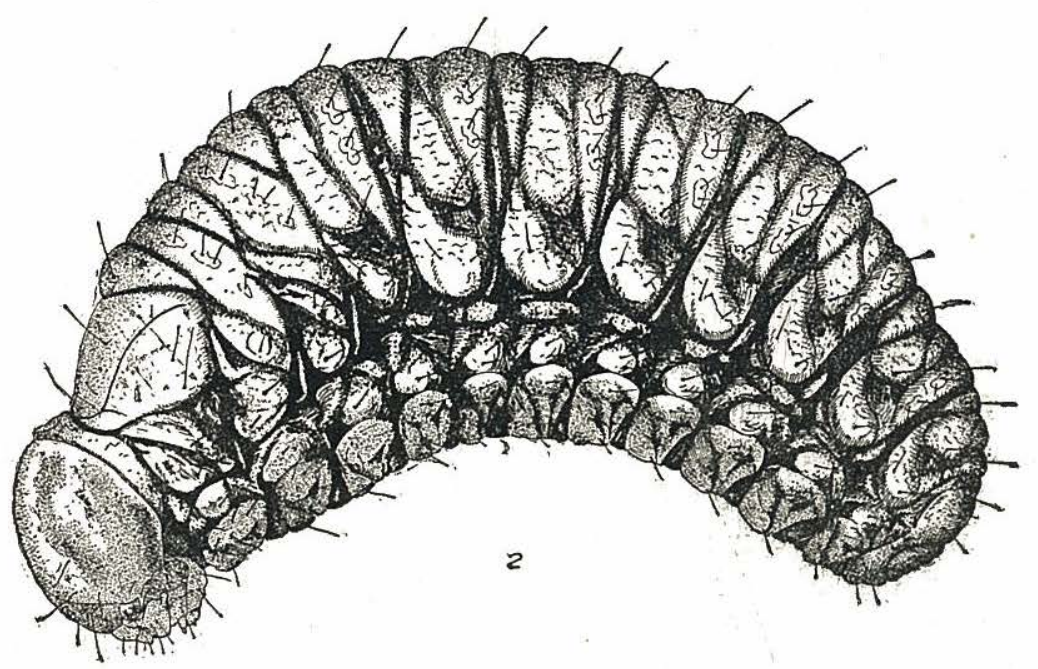

Fig. 3. Larva of Diaprepes abbreviatus L., five times natural size. (After Pierce.) 
The escaped grubs move across the leaf with a peculiar galloping motion, and when they come to its margin, fall off. They do not burrow into the ground, and if (experimentally) it consists of finely sifted soil moderately well packed and without a crack, they contnue to gallop about for several days, sometimes until their activities have sufficiently discurbed the surface of the soil so that they fall into cracks accidentally, and disappear beneath its surface. Ever then, they show no inclination to stay benesth the surface, and a few will ordinarily be moving actively about at or just beneath its surface for a week or more after haiching. In nature, unsifted soil is so full of cracks that they promptly fali into one, and gradually work their way down into the soil so deeply that, barring accidents, they will not again appear at the surface until they become adult beetles. Some of the grubs happen to come in contact with minute rootlets, and eat and grow big enough to molt to second instar within a few days; others may wander about for a week or longer, apparently without eating, and some are still in the fir'st instar while others of the same egg-cluster have grown to third instar size. Presumably scme or most of these grubs which fail to come in sontact with suitable food, or fail to learn to cat it within the first few days after hatching, also fail entirely and irrevocably, but others, even as long as two weeks after hatching, finally do eat and grow, and altho retarded at the beginning in their rapidity of growth, pupate at almost exactly the same time as do the most rapidly growing of their brothers and sisters, and develop into adults quite as vigorous. Apparently the margin of survival here is very broad, extensive enough to allow for several days at least after hatching before the grubs escape from the egg-cluster, and, if not needed there, equally useful before the grub must find food in the ground.

Presumably the grubs feed on any kind of living root of suitable size with which they come in contact in the ground. Definite records are available of their being collected in the field attacking only the roots of sugar-cane, grapefruit, pepper, lima bean and yuca. Lima beans were used as food for some of the grubs in the laboratory, but the bulk of them were reared on corn. The attack of the larger grubs on the root-stalks of sugarcane, into which they burrow, has long been known, and has been considered the principal injury to economic crops caused 
by this pest. The small grubs do not hesitate feeding on roots too small for them to burrow inside of, and indeed the habit of

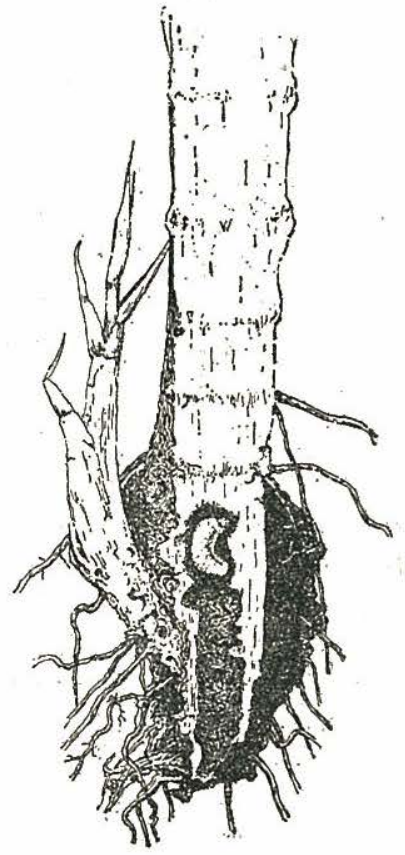

Fig. 4. Larva of Diaprepes abbreviatus L., feeding in root-stalk of sugar-cane. One-half natural size. (Drawn by F. Seín).

burrowing inside of their food supply seems not to be well developed until they are partly grown. The smallest grubs have not been noted burrowing into kernels of corn, but only feeding on corn rootlets from the outside, but third and forth instar grubs often burrow inside dry and unsprouted kernels of corn, growing much more rapidly than others on the outside feeding on the roots or rootlets.

The grubs of Diaprepes are apparently so well able to withstand long periods of fasting at any time in their growth that only the outmost care in continually providing fresh and attractive food in abundance is the experimenter able to induce them to feed to capacity and make most rapid gains in weight until full size is attained. By comparison with the industrious manner in which caterpillars feed, the grubs of Diaprepes are 
most dilatory, and only when they are completely surrounded by food do they display their maximum capacity for rapid growth. As shown by the number of days for them to reach sixth instar, the rapidity of their growth is as follows: for those hatched in March 79 days, for those hatched in May 80 days, in June 55 days, in July 55 days, in August 57 days, in September 42 days, in October 54 days, in November 51 days, in December 46 days and in January 50 days. If dependence may be placed on these data, obtained from eighteen eggs clusters in ten months, slowest growth from grubs hatching in the spring is indicated, and most rapid growth of grubs hatching early in the fall. The extremes are represented by one grub hatching in September which attained sixth instar in 27 days from hatching, and another hatching in March which required 126 days to attain the same size, extremes, however, which are typical of all grubs hatching in the autum versus those hatching in the spring.

By comparison with the variations in some other periods of the insect's development, that in growth seems insignificant, but if it means anything at all, it may be part of the tendency of the individuals concerned to return to a year life-cycle, with the eggs normally laid in the summer. So far as can be determined, it is not a reaction to temperature, as the seasonal variation of the temperature means averaged only $10^{\circ} \mathrm{F}$. at Rio Piedras $\left(12^{\circ} \mathrm{F}\right.$. between minimums, $8^{\circ} \mathrm{F}$. between maximums, recorded in the Insectary beside the rearing cans and tubes), or only half the difference between the average day and night extremes of the twenty-two months of which the records were kept. Thus, while grubs grew most rapidly in September, and most slowly in March and May, those from eggs hatching in June, July and August paralleled in rapidity of growth those hatching in October, November, December and January. It should be especially noted, also, that the seasonal variation in rapidity of growth is by no means as great as the individual variation shown by grubs from the same egg-cluster.

As previously noted (21), the minimum time in which a grub has been reared to full size (eighth instar) is 48 days, and another grub from the same egg-cluster, 53 days, but two other grubs from the same egg-cluster, which required over twice as long to attain the same size, pupated and shortly afterward transformed to adult at practically the same time. Molting to 
Variation in Rapidity of Growth of Larvae of Diaprepes abbreviatus L., as shown by 140 individual records in 2nd Instar (left), 170 individual records in 4th Instar, 193 individual records in 6th Instar and 130 individual records (for growth period only) in 8th Instar (right).

Each horizontal series of squares in an instar group represents one individual record (those in the same line in different instar groups are rarely and only accidentally of the same individual); the number of squares indicates days, the distance between the two vertical lines represents 100 days, the one on the left being date of hatching of the larva from the egg.

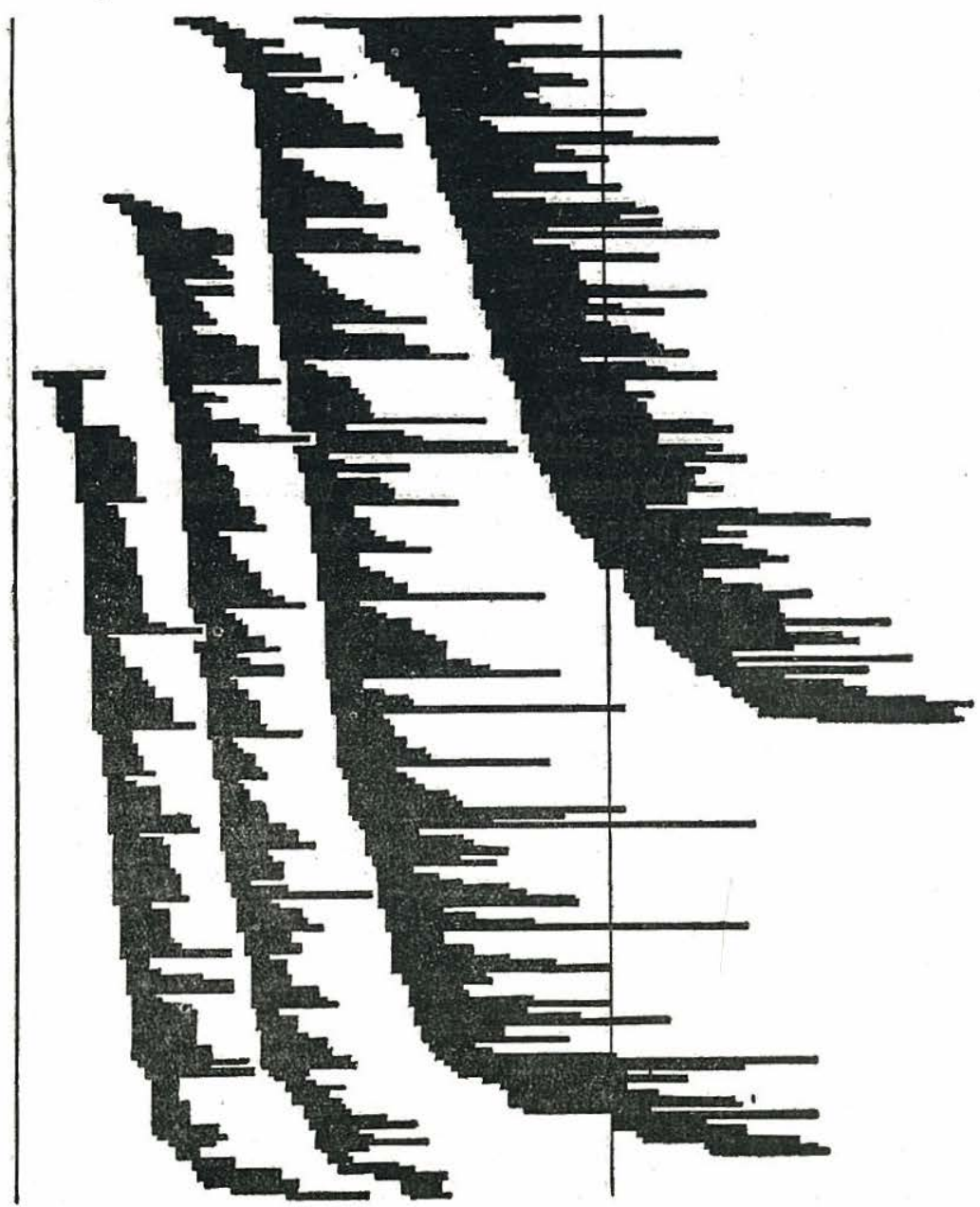


eighth instar has been taken to mark the time of maximum weight, but unfortunately for consistency in making the records, many grubs do not molt that many times as larvae, but pupate from the sixth instar. "Thus, to make all data comparable, the records have been grouped on the basis of the rapidity with which the grubs reached sixth instar. They indicate tremendous variation in rapidity of growth in the various larval instars, a variation which is even more obvious in the accompanying graph. (See graph.)

The grubs of Diaprepes may have as few as six larval molts before pupation, but normally have eight, and may have many more. Before the experimenter realized the necessity of the grubs for a diapause period during or after growth, and while he was continuing to supply them with an abundance of food, which they half-heartedly attempted to consume, some of them molted as many as a sixteen times, one successfully pupated after molting fifteen times, another after thirteen molts, one after twelve, two after eleven, and many after molting ten or nine times as larvae. Ordinarily, larval molts exceeding the usual number are a reaction to unfavorable conditions such as cold, or lack of food, but in the case of Diaprepes, the unfavorable condition appears to have been a surplus of food.

A diapause period in the life-history of Diaprepes is not only normal, but apparently essential before the fully-grown grub can pupate. At the beginning of this period, the grub is very active, and presumably in nature may travel to considerable distances in the ground. It eats, more or less, but continually less, and becomes less active as the period of pause lengthens. Normally, it does not molt, and the period from the last larval molt until pupation may be considered the extent of this period of waiting.

The diapause period may be for less than two months, or it may be for nearly thirteen months. Its extent is not appreciably affected by previous rapidity of growth, the time of the last larval molt, humidity of the soil, temperature or time of year. So far as the writer can determine from the data available, it is entirely unpredictable. For instance: of two grubs hatched in September, one, molting to ninth instar after 144 days, waited 315 days before pupating, the other, molting to eleventh instar after 115 days, pupated in 55 days. These grubs 


\section{TABLE No. 2}

Duration in Days of Diapause Periods of Larvae of Diaprepes abbreviatus L. grouped according to the Month in which the Larva Hatched.

November December January March July September

137

55

55

68

75

76

89

90

91

90

94

95

106

102

23

124

129

124

131

132

133

$134 \quad 133$

138

$140 \quad 142$

153

145

152

155

157

156

169

171

172

172

187

175

185

197

199

193

$202 \quad 200$

223

223

200

220

226

231

246

241

244

233

250

255

250

250

266

261

277

264

271

283

282

291

297

299

299

318

341 
were side by side in identical glass tubes, receiving the same amount of moisture from the moistened sand below. The diapause periods of others from the same egg-clusters, which had grown very rapidly were: $65,68,76,89,90,102,155,156,169$, 226, 233 and 267 days after the last larval molt. Other grubs from the same lots, which grew more slowly had diapause periods of $91,106,129,134,135,140,172,175,197,199,200,244,261$, 264, 271, 291, 347 and 388 days. There appears to be no consistency here. Out of twenty-six grubs hatching in November, December and January, twenty-two had diapause periods of eight months and longer, the two longest being 318 and 341 days. The only group of grubs showing any consistency are those hatching in July, all twelve of which had diapause periods of four to five months. That is, of this group only, one might with reasonable confidence predict the extent of the diapause period. (See Table No. 2)

If one is to suppose that the grubs hatching in July (or a little earlier or a little later) from eggs laid in June, represent the normal, original life-cycle, that they should all attain full size at about the same time and all be ready to pupate at about the same time seems only reasonable. As has been previously pointed out however (21), the egg parasite, Tetrastichus haitiensis Gahan, is most abundant in June, consequently few grubs survive from eggs laid at this time. Survival, for Diaprepes $a b$ breviatus wherever this parasite is present, depends largely on being different, on deviating from the normal, and thus bringing the period of oviposition at a time of year when the egg parasite is scarce. The period of incubation of the eggs is very definitely fixed at seven days, that of growth varies only from two to four months, and that of the pupa from fourteen to twenty-six days, and that of the aerial adult female is but little more than the time necessary to lay her eggs. The two perods least defintely fixed, or susceptible to the greatest variation, are as adult in the soil or as a larva in the diapause period. The maximum recorded diapause period, 388 days, is seven times that of the minimum, 55 days.

Early in the diapause period the grub wanders about in the soil with tremenduous energy, in captivity churning up the small amount of soil available in its restricted quarters and breaking off the roots of any plant growing within the container. 


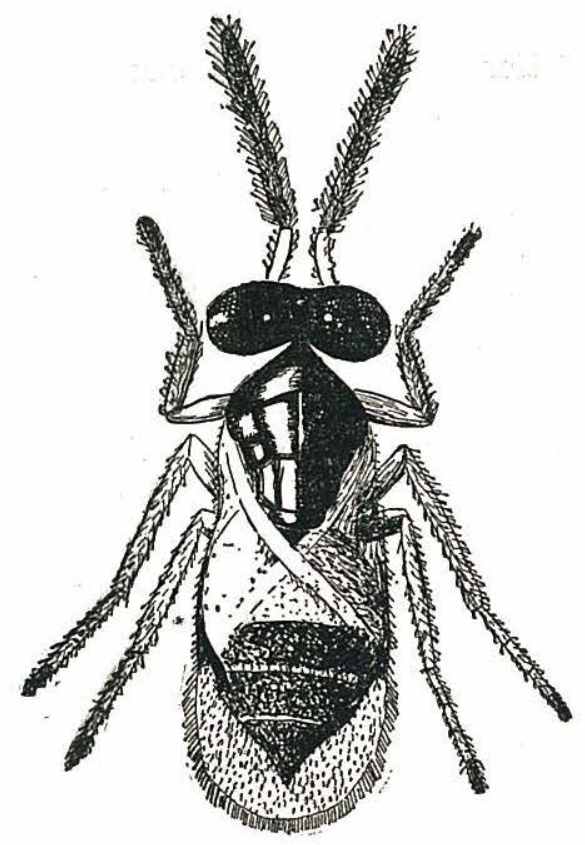

Fig. 5. Tetrastichus haitiensis Gahan, sixty times natural size. (Drawn by G. N. Wolcott.)

In nature, its wanderings are directed towards no fixed goal, and it may eventually come to rest close to where it started, yet many grubs, by accident, doubtless wander far afield. The survival value of this display of energy is not obvious, and seems to lead nowhere. It may be an attempt to escape from externally parasitic mites. These mites; determined by Dr. H. E. Ewing, of the U. S. National Museum, as Rhizoglyphus phylloxerae Riley, first appear on the head and body of the grub when it is about half grown, continuing to be present in increasing numbers on some individuals until pupation. At each molt the grub escapes from the mites if it moves away soon afterwards from the molted skin to which the mites still remain attached, but this easy escape from their tormenters is no longer available during the diapause period, when it does not normally molt. The mites can be dislodged artificially by rubbing, and possibly some of them are rubbed off by the grub in rapidly making its way thru the soil. The grub appears to show no deleterious ef- 
fect from a light infestation of mites, but when they completely cover the head and fore part of the body, one may be reasonably sure that that particular grub will not survive to become adult. Of course such heavy infestations are presumably due to the artificial conditions and close quarters under which the grubs are reared, and would occur but rarely, if at all, in nature.

The wandering of the grub during the diapause period may also tend to lessen the mortality caused by the Green Muscardine fungus, Metarrhizium anisopliae Sorokin, by shifting the position of the grub in the soil to localities where the humidity is less favorable to infection by and growth of the fungus. Numerous grubs, many pupae and a few adult beetles (while still in the soil) died as a result of infection by the Green Muscardine. In most cases, the insect was accidentally injured, mite-infested, or sub-normal before infection by the fungus took place, and no instance can be recalled of any insect supposed to be entirely normal and healthy sucumbing to infection by the Green Muscardine. Indeed, many mite-infested and subnormal individuals seemed to have surprising high resistance to fungus infection, and often lived for days, weeks, or even months before finally succumbing to attack. Thus, the conclusion of the experimenter is that this fungus is not strongly pathogenic, but merely is the first to develop in insects about to die primarily from some other cause. The many deaths of grubs recorded as being due to this fungus or to mass infestations of mites are in reality due to the somewhat abnormal conditions under which the grubs were reared, and dropped considerably towards the end of the investigation when rearing methods had been more nearly perfected. Under normal conditions in the field, it is believed that neither the mites nor the Green Muscardine are of importance in causing larval mortality of Diaprepes.

Indeed, the extraordinary energy displayed by the grub in wandering about at the beginning of the diapause period seems almost inexplicable, as it does not terminate in the selection of a different and more desirable location for the pupal chamber, as at the very end, the more or less quiescent grub again changes its position. Thruout the diapause period the grub rests or travels horizontally or transversely in the soil. When ready to pupate, however, it forms a vertical chamber in the soil, and rests in it with the head up. It is a very active, and 
spins round and round on its caudal end in the pupal chamber, compacting the soil of the walls. Pupation occurs within two or three weeks after the chamber is formed.

Pupae are formed in every month of the year, but of the records available, nearly one-third are in the month of March. Almost a sixth are in the month of October, with no definite trends for the other months. Obviously, March is the normal, original month, the others quite as obviously being wide variations from this norm. Fifty records are available as to the duration of the pupal period, but due to the difficulties of observation in many cases, too much exactitude can not be claimed for all of them. Nine days is the recorded minimum (which seems doubtful), but almost a third are of 14, 15 and 16 days, and slightly more than two weeks seems normal. The bulk of the records are from 17 to 26 days, the few of greater length being of doubtful verity.

When first formed the pupa is entirely waxy white, but a few days before the adult is to emerge, the eyes of the pupa begin to darken, the claws are seen to be black, and the underwings are clouded with grey. The color deepens rapidly, and within a few days the adult will have crawled out of the pupal skin. Within a day it is fully colored, at least in the chambers which were open on one side for observation. Whether the color transformation is as rapid as this in complete darkness was not determined. The adult remains quietly in its pupal chamber long after it is apparently hard and physically able to emerge. To determine what factors might be responsible for the emergence of the adults from the ground, complete daily records of maximum and minimum air temperatures were kept, and some tubes watered profusely from the top, while others received only the moisture coming up from the wet sand below. While one or two adults might appear to have been affected by sudden temperature changes, or hurricane weather, or excessive moisture, so many others were unaffected that the only conclusion reached from the experimental evidence was that the adults emerged entirely without reference to external factors.

Eleven days is the minimum recorded time for the adult vaquita to remain in the pupal chamber before coming to the surface of the ground and 126 days the maximum, or twelve times as long. The length of the period appears to be entirely fortuitous: of the forty-six records, somewhat over a third are 
between 33 and 48 days, and nearly half are for over two months. The records of individuals which hatched from eggs in July show not quite as much variation as do all the others, the extremes being 20 and 92 days, and over half being between 33 and 48 days. Possibly in nature, continued heavy spring rains would be more effective in bringing most of them to the surface at one time than the temporary drenchings experimentally attempted in the tubes, indicating that five or six weeks may be normal extent of this period. The suddenness with which numerous adults appear in Barbados after the spring rains have commenced, following a comparatively dry winter, has suggested the probability that the rains are the stimulus causing pupation (13). It seems much more likely that the rains are the stimulus for the emergence of the adults, as pupation presumably took place several months previously. Since no egg parasite of Diaprepes occurs in Barbados, the insect is not faced with the necessity of varying from its normal life-history if it is to survive, and consequently most of the adults appear at one time in the spring.

During most of the period when the adult is in its pupal cell, it appears ready to emerge at any time, being completely hardened, and, if disturbed by having its cell broken into, will crawl out immediately and act as tho it had emerged normally. If replaced in its cell, and the top layer pressed into place, it may remain there for the time beiny, but in every case was at the surface of soil by the next morning. In the summaries of life-histories, no distinction is made as to whether the time of emergence was normal or artificially induced, and is indicated as "up".

The Otiorhynchid, or "scarred-snout" beetles, to which group Diaprepes and allied species belong, are characterized by scars at the end of the beak marking the disappearance of the so-called "mandibular appendages," which, in the case of Diaprepes, are prominent, curved, black claws, even larger than the jaws with which the insect eats. The presumed purpose of these mandibular appendages is to enable the insect to make in June of the second year following, and two others (which buried pupal chamber, and they are supposedly just strong enough for this, yet so insecurely attached to the beak that they will fall off soon afterwards (being no longer needed by 
the insect), leaving scars on the beak where they were attached. The pupal chamber of Diaprepes normally occurs at a considerable depth in the ground, at a much greater depth than could be obtained in the glass tubes used in the rearing experiments. Consequently, in digging their way out thru the comparatively small amount of earth over their pupal chambers, several of the beetles failed to dislodge these mandibular appendages, one or both of which remained attached as long as the individuals lived. They appeared to be very much in the way of the insect when feeding, the punctures made by the appendages being very noticeable beside the margins of the leaves where these beetles had been eating. Most of the individuals failing to loose these claws were males, the results of this abnormality in three cases resulting in the untimely death of their mates. One can not be sure that the presence of these claws on the jaws of the male was responsible for the death oi the female, yet no more females died when supplied only with males lacking these formidable appendages, and the evidence seems reasonably conclusive. In nature, such occurrences would be rare, if they occurred at all, and in the present instance were due to the interference of man.

The total life-cycle of Diaprepes may be considerably less than one year, or it may be over two years. It must be admitted that no individual records of the latter maximum have been obtained, but that they actually occur seems quite certain. The minimum period is of larvae which hatched from the egg in September, and of which adults emerged from the ground by the following April. Within less than a week after the female adult has emerged from the ground sne begins to lay eggs, and by a week later these eggs have hatched. This is not an exceptional or unusually short life-cycle for the insect, as all of the reared individuals hatching in July, and the bulk of those hatching in September completed their development in a month less than a year.

By contrast, all of the grubs hatching during the winter months required at least a year for their development, most of them several months longer, and of those hatching in January, records are available of one female emerging from the ground in June of the second year following, and two others (which escaped without their sex being determined) in July of the second year. Altho some females have finished laying all of 
their eggs within two months, others require more than twice as long, and one is recorded as requiring nearly seven months after emergence from the ground before she had laid her last egg. From egg to egg in this (theoretical) instance over two years elapse.

Presumably the normal, original life-cycle approximated one year, with the adults appearing above ground in the late spring and early summer. Most of the females appearing at this time of year lay all of their 5,000 or more eggs in less than two months, thus, altho some scattering might occur, most of the individuals would maintain the one year life-cycle. Judging by the records available, the grubs from the earliest egg-clusters (May) would be slowest in developing to adults (May to August), and those from the latest (September) most rapid (April and May).

Opposed to this tendency of some individuals to return to the normal one year Jife-cycle, is that of others, farthest removed from the normal time of egg-laying, to develop a much longer cycle shown in the records by one September-hatched grub emerging as adult in the second November following, November and December-hatched grubs emerging in the second April following, and January and March-hatched grubs with emergences of adults scattered from the following December to. June and July of the second year. (See Table No. 3.)

The total number of rearing records on which this paper is based is close to two hundred forty, and even of the life-cycles completed to the natural death of the adult is so large as to preclude publication in full. Yet it seems desirable to present some presumably typical case histories. In all of these, the number of days given is from date of hatching of the egg. The numbering of the individual is a decimal, that of the egg-cluster from which it hatched is the whole number preceeding the decimal point. Ordinarily, the most rapidly growing grubs were separated from the others from an egg-cluster when in third instar, and given a number at this time; thus .1, .2, .3, .4, etc. are presumably the most vigorous grubs, while .11, .12, .13, etc. are less rapidly growing grubs, separated from the others at a later date, and .00 , and .0 are the runts, those left in the original can after all the other larger ones had been removed and placed in separate cans. 


\section{TABLE No. 3.}

Month of Emergence from Pupal Cell of Adult of Diaprepes abbreviatus L., arranged according to the Month in which the Larva Hatched.

\begin{tabular}{|c|c|c|c|c|c|c|c|c|c|c|c|c|c|}
\hline \multirow{2}{*}{$\begin{array}{l}\text { Month } \\
\text { Larva } \\
\text { Hatehed. }\end{array}$} & \multicolumn{13}{|c|}{ Adult emerged from pupal cell in montil of: } \\
\hline & Nov & Dec & Jan. & feb. & Mch. & Apr. & мay & June & July & Aug. & sept. & oct. & Nov. \\
\hline November & ? & 우 & oे & q & & ? ? & & & & & & & \\
\hline December & & $q$ & & & & రే & & & & & & & \\
\hline January & & $\sigma^{2}$ & $\begin{array}{l}\delta \\
?\end{array}$ & & & $\begin{array}{l}0 \\
0 \\
+9\end{array}$ & $?$ & 우 & ?? & & & & \\
\hline March & & $?$ & 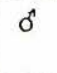 & & $\begin{array}{l}0^{2} 07 \\
+ \\
+\end{array}$ & $\alpha_{i}$ & & 우 & & & & & \\
\hline May & & & & & ? & & $\begin{array}{l}\text { q } \\
?\end{array}$ & & & ô & & & \\
\hline July & & & & & & ??? & 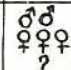 & $? ?$ & & & & & \\
\hline September & & & & & & 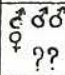 & ??? & $\begin{array}{c}\text { q } \\
\text { ??? }\end{array}$ & $\begin{array}{l}\text { की } 0^{7} \\
\text { ?? }\end{array}$ & 8 & $\vec{\sigma}$ & & 우 \\
\hline
\end{tabular}

Diaprepes abbreviatus L. individual No. 44.1 hatched from the egg September 7, 1933, molting to successive larval instars up to and including the tenth in $7,11,15,20,27,34,48,95$ and 117 days, having a diapause period of 76 days before pupating on the 193d day (March 19th, 1934), transforming to a female adult on March 28th, and coming to the surface of the ground on April 30th. She was one of three females whose combined egg production was 17,050 eggs, and she died on July 3, 1934, 299 days after hatching of the larva from the egg.

Inividual No. 44.3 molted to the tenth larval instar on the 119th day, and was noted as a soft adult on March 27th, but did not come to the surface of the ground until June 26th. She laid 7,046 eggs, and was very tenacious of life, appearing dead on October 3rd, but was not actually devoid of life until Oct. 
10, 1934, at which time she weighed $.345 \mathrm{gr}$. From date of hatching, she had lived 398 days.

Individual No. 44.8 molted to the tenth larval instar on the 105th day, but had a diapause period of 263 days before pupation. The male adult was first noted on September 25th, over a year after the date of the hatching of the larva, came to the surface of the ground on October 23d, and was dead by November 26 th, weighing $.144 \mathrm{gr}$. at time of death.

Individual No. 44.24 molted to the ninth larval instar on the 100th day, and pupated 94 days later. The adult male emerged from the pupal cell on July 18th, having been there as a fully-formed adult since April 4th. He died on August 11th, 27 days less than a year after the grub had hatched.

Individual No. 45.3 hatched from the egg on September 11, 1933, molting to successive larval instars up to and including the eleventh in $10,22,26,30,36,49,60,81,94$ and 115 days respectively, and with a diapause period of only 55 days, transformed to pupa on March 1st. Becoming adult on the 19th, a male came to the surface of the ground on April 28th, and was dead June 7 th, or 96 days less than a year after the grub had hatched.

Individual No. 47.5 hatched from the egg on November 24,1933 , molting to successive larval instars up to and including the ninth in $10,17,25,36,41,56,68$ and 89 days, had a diapause period of 246 days, not becoming a pupa until October 25th of the next year. Development thereafter was rapid, however, a female adult weighing $.32 \mathrm{gr}$. emerging from the pupal cell on December 22nd. She laid 2,109 eggs before being found dead on January 21, 1935, presumably having been murdered by 8.00, a male which still had his mandibular appendages. At death she weighed $.313 \mathrm{gr}$.

Individual No. 47.4 had an even longer diapause period of 265 days, after having molted to eighth on the 89th day. A soft adult was noted in the pupal cell on December 2nd, but the female did not emerge until February 8, 1935. She began laying eggs on the 15th, and had laid 1,675 before March 15th, on which day she was found dead. The male with her, No. 5.6, had no 
mandibular appendages. When she emerged from the ground she weighed $.331 \mathrm{gr}$. , and at time of death $.35 \mathrm{gr}$.

Individual No. 47.00 was the slowest to grow of all the grubs hatehing from the egg-cluster, but entering the diapause period from the seventh instar on the 74th day, was not observed making a cell until November 13th. The adult was first noted on December 8th, a female which came to the surface on February 12th, and laid 4,982 eggs before she was found dead on June 12th. At emergence from the ground she weighed .163 gr., and at death $.157 \mathrm{gr}$.

Individual No. 5.5 hatched from the egg on January 5, 1934, molting to successive larval instars up to and including the eighth in $9,18,28,38,45,66$, and 94 days, and did not transform to a pupa until over a year from the time of hatching. An adult male weighing .17 gr. came out of his pupal cell on April 12th, and lived until July 1, 1935. At time of death he weighed only $.055 \mathrm{gr}$.

Individual No. 5.2 almost exactly paralleled her brother, emerging from her pupal cell on April 9th, weighing .34 gr., and was released.

Individual No. 6.2 hatched from the egg on January 14, 1934, molting to successive larval instars up to and including the seventh in $11,15,27,33,52$ and 80 days, pupating on November 27th, and transforming to adult on December 18th. The adult male came out of his pupal cell on January 21st, weighing .266 gr., and lived until June 26th, weighing .252 gr. at time of death. This male outlived the female 47.00 , with which he was confined, and possibly may have murdered her, altho possessing no mandibular appendages at the time of emergence from the soil. A total of 537 days elapsed from date of hatching of the egg till the death of the male beetle.

Individual No. 6.7 molted to 6 th in 56 days, but waited until the 113th day before molting again, and pupated 282 days later. The adult was noted on March 11th, but did not come to the surface until June 10th, a female weighing .286 gr., who was released.

Individual No. 7.1 hatched from the egg on March 1, 1934, molting to successive larval instars up to and including the 
eighth in 14, 20, 30, 39, 63, 72 and 126 days respectively. After 264 days of waiting, it pupated on March 26th, 1935, the adult being noted on April 15th, and emerging as a male on May 11th, weighing .157 gr. He died on July 22nd, weighing only .095 gr. at time of death.

Individual No. 7.5 molted to the seventh larval instar in 135 days, but was observed in a cell by December 24th, and had become a pupa by January 4th. The male adult appeared March 29th, weighing .15 gr., and living until August 19th, at which time he weighed $.16 \mathrm{gr}$.

Individual No. 7.4 molted to 9 th on the 136 th day, had become a pupa by October 24th and transformed to adult by November 11th. The female adult did not appear above ground, however, until March 12th of the following year. She lived until October 14th, and laid 5,219 eggs, at time of death weighing $.193 \mathrm{gr}$.

Individual No. 7.6 molted to 7 th on the 91 st day, waiting until exactly one year after date of hatching before transforming to pupa. She appeared above the surface of the ground as a female beetle on June 7th, weighing $.175 \mathrm{gr}$., was confiner with her brother, 7.5, and laid 5,045 eggs before her death on October 26th. On the 18th, she weighed $.246 \mathrm{gr}$. , on the $23 \mathrm{~d}$, $.222 \mathrm{gr}$., and when dead, .21 gr.

Individual No. 9.1 hatched from the egg on May 11, 1934, molted to successive larval instars up to and including the sixth in $20,35,50,69$, and 87 days respectively, but waited over 9 year after date of hatching from the egg before being observed to be forming a pupal cell. An adult male, weighing .153 gr. appeared above ground on June 19th, and died towards the end of October.

Individual No. 10.2 hatched from the egg on May 15, 1934, molted to successive larval instars up to and including the seventh in $36,47,65,72,83$ and 122 days respectively, transformed to a pupa by January 21st and an adult by February 14th. A female adult weighing $.127 \mathrm{gr}$. appeared on May 29th, began oviposition on June 17th, and by October 25 had laid 3,335 eggs, being confined with the male 9.1. On October 28th she weighed .222 gr., and on November 3d, .133 gr., apparently having died a day or two earlier. 
Individual 935.1 hatched on June 7, 1934, from an eggcluster collected at La Indiera in the mountains north of Yauco, and molted to successive larval instars up to and including the seventh in 14,20,28,32, 47 and 98 days respectively. On September 13th, it weighed .408 gr., and on February 21, 1936, $.269 \mathrm{gr}$., indicating a considerable loss of weight during the diapause period, altho this may in considerable part have been due to lack of attention for the preceeding month.

Individual No. 935.14 had just molted to the sixth larval instar on the 57th day after hatching, at which time the grub weighed .288 gr. When examined on February 22nd, it had become a male adult weighing $.197 \mathrm{gr}$., which was released.

Individual No. 43.1 hatched from the egg on July 21, 1933, molting to successive larval instars up to and including the eighth in $22,28,34,48,52,71$ and 91 days respectively, and after a diapause period of something less than five months, was noted as a soft adult in the pupal cell on March 26th. Appearing above ground on May 7 th, this was one of the females which, with 44.7 and 43.0 , laid a total of 17,050 eggs. She diec on July 16 th.

Individual No. 43,0 grew just as rapidly up to the 5th instar, but after that the molts were on the 56th, 67th, 80th and 101st days. The pupa was observed on March 17th, and the soft adult on the 26th, the female appearing above the surface on May 7th. She was confined with 44.7 and her sister 43.0, and three males, being found dead on July 16th.

Individual No. 42.0 hatched from the egg on July 26, 1933, molted to successive larval instars up to and including the sixth in $12,17,35,45,52$ and 92 days respectively, and was first noted as a pupa on March 20th. Transformed to a soft adult by April 4th, the male appeared above ground on May 11th, and had died by June 20th, or almost exactly a month less than a year after the egg was laid.

Individual No. 40.2 hatched from the egg on July 28th, 1933, molted to successive larval instars up to and including the tenth in $14,21,30,39,45,54,73,81$ and 102 days respectively, and was first noted again as a soft adult on March 26th of the following year. The female emerged on May 11th from the ground, and being confined with the male 42.0, who had 
emerged on the same date, outlived him by only a week, laying 2,916 eggs before her presumably premature death.

Thus reduced to the essential outline, there appears to be such a similitarity about these case histories that the fundamental differences escape observation. It is only when the details of all of them are compared that the differences become obvious, as is indicated, it is hoped, in the first part of this paper. Looked at in another way, there is something touchingly human about these bare records, like those carved on the tombstones of a cemetery, only the wealth of incident due to a more complicated insect life-cycle necessarily gives them fuller detail between the two termini of birth and death.

\section{SUMMARY}

1. The females of Diaprepes abbreviatus L. lay 5,000 or more (or less) eggs in as few as two months, May and June, or in as many as seven months at other times of the year, often living over twice as long as do the males after emergence from the soil.

2. The incubation period of all eggs is seven days. Larvae attain full size in two to four months. A diapause period is absolutely essential before pupation. The pupal period is about two weeks. Fully-formed adults remain within the pupal chamber for a variable period of weeks or months, the length of this period and that of the diapause period of the larva being subject to great variation.

3. The great variation in the duration of the diapause period of the larva and before the emergence of the adult from the pupal cell in the ground permits some individuals to complete their life-cycle (hatching of eggs to first egg-cluster laid by female, or to emergence of male from soil) in less than eight months, but for other individuals it may extend for eighteen months (hatching of egg to last egg-cluster laid by female, or to death of male).

4. Deviation from a one-year life-cycle is of tremendous value to Diaprepes abbreviatus L. in enabling its eggs to escape attack by a common parasitic wasp, Tetrastichus haitiensis Gahan, which is most abundant during the late spring, but very scarce during autumn and winter. 


\section{BIBLIOGRAPHY}

1. Ballou, H. A., "Insect Pests of the Lesser Antilles" Pamphlet Series No. 71, Imperial Dept. Agr. W. I., pp. 210, fig. 185. Barbados, 1912. (see pp. 66-69, figs. 70-73.)

2. Bruner, S. C., "Observaciones sobre le Picudo Verde-Azul de los Naranjos." Rev. Agr. Comericio y Trabajo, 14, (19) : 35-40, fig. 2, tab. 1. 1934. (tests of control measures).

3. Cook, M. T. \& Horne, W. T., "Insects and Diseases of the Orange." Bul. No. 9, Estación Central Agronómica de Cuba, pp. 44, pl. 19. 1908. (see pp. 11-17, pl. 5-6).

4. Cotton, R. T., "The Larva of the Weevil

Exopthalmus quadrivittatus (Olivier)." Proc. Wash. Ent. Soc. 31, (2) ; 27-31, pl. 1. Washington, D. C., February 1929. (a detailed description and comparison with that of Diaprepes abbreviatus).

5. Dozier, H. L., "Descriptions of New Trichogrammatid (Hymenoptera) Egg Parasites from the West Indies." Proc. Wash. Ent. Soc., 34, (3) ; 29-37. 1932. (original description of Ufens osborni).

6. Gahan, A. B., "Description of an Egg-Parasite of Exopthalmus quadrivittatus (Olivier)." Proc. Wash. Ent. Soc., 31, (1) ; pp. 17-18. 1929. (original description of Tetrastichus haitiensis).

7. Hutson, J. C., "Some Weevils of the Genus Diaprepes in the West Indies." Agr. News, 16, (395) : 186. Bridgetown, Barbados, June 16, 1917, and (399) : 251, Aug. 11 1917.

8. Jones, T. H., "The Sugar Cane Weevil Root Borer (Diaprepes spengleri Linn.)." Bull. 14, Insular Experiment Station, Rio Piedras, P. R., pp. 19, fig. 11. 1915.

9. Marshall, G. A. K., "On New Neotropical Curculionidae." Annals \& Magazine of Natural History, (Ser. 8), 18: 449-469. London, December 1916. (includes on p. 451 a discussion of the nomenclature used by Pierce (14). 
10. Marshall, G. A. K., "On New Genera and Species of Neotropical Curculionidae." Trans. Ent. Soc. London, Parts I \& II. pp. 181-224, pl. 2. London, July 31, 1922. (contains, on p. 189, a discussion of the genus Exophthalmodes Pierce.)

11. Myers, J. G., "A Preliminary Report on an Investigation into the Biological Control of West Indian Insect Pests." Empire Marketing Board, 42, pp. 173, pl. 2, many ref. London, July 1931.

12. Nowell, Wm., "Field Investigation of Beetle Grubs Attacking Roots of Sugar-Cane.” Rpt. Local Dept. Agr. Barbados 1911-12, pp. 50-51. 1912.

13. Nowell, Wm., "Report of the Assistant Superintendent of Agriculture on the Entomological and Mycological Work carried out during the Season under Review." Rpt. Local Dept. Agr. Barbados, 1912-13, pp. 34-45.

14. Pierce, W. D., "Some Sugar-Cane Root-Boring Weevils of the West Indies." Jour. Agr. Research, 4, (3) : 255267, pl. 4. Washington, D. C., June 15, 1915. (excellent illustrations.)

15. Watson, N. B., "The Root-Borer of Sugar-Cane (Diaprepes abbreviatus)." West Indian Bulletin, 4, (1) : pp. 37-47 fig. 3. 1903.

16. Wolcott, G. N., "Vaquitas de Importánica Económica en Puerto Rico." Circ. No. 60, Est. Expt. Insular, Río Piedras, P. R., pp. 20, fig. 20. 1922.

17. Wolcott, G. N., "Notes on the Life-History of Exopthalmus quadrivittatus Olivier (Coleoptera)." Proc. Washington Ent. Soc., 31, (2) : 21-26. Washington, D. G., February 1929.

18. Wolcott, G. N., "An Economic Entomology of the West Indies." pp. xviii \& 688, fig. 111. Ent. Soc. of P. R., San Juan, September 1933. (see pp. 134-142 \& 450461.)

19. Wolcott, G. N., "The Larval Period of Diaprepes abbreviatus L." Jour. Dept. Agr. P. R., 17, (3) : 257-264, pl. 1, tab. 1, ref. 2. 1933.

20. Wolcott, G. N., "Otiorhynchids Oviposit between Paper." Jour. Ec. Ent., 26, (6) : 1172-1173. 1933.

21. Wolcott, G. N., "The Diapause Portion of the Larval Period of Diaprepes abbreviatus L." Jour. Agr. Univ. P. R., 18, (3) : 417-428, fig. 1, pl. 1, ref. 1. 1934. 